\title{
Pruning intensity and amino acids tryptophan and glycine on growth and flowering of Jasminum sambac
}

\author{
Ziyad Khalf Salih ${ }^{1}$ (D), Seyedeh Somayyeh Shafiei Masouleh²* (D, \\ Mohamed Abdulla Ahmed ${ }^{1}$ (D), Marwan Abdulla Sanam ${ }^{1}$ (D) \\ ${ }^{1}$ Tikrit University, Agriculture College, Horticulture and Landscape Department, Iraq. \\ ${ }^{2}$ Ornamental Plants Research Center (OPRC), Horticultural Sciences Research Institute (HSRI), Agricultural Research, \\ Education and Extension Organization (AREEO), Mahallat, Iran.
}

\begin{abstract}
Jasmine (Jasminum sambac L.) is an evergreen shrub and very fragrant, which has a very importance in the perfume industry and its flowers are used in different religious and ceremonies. Training the shrubs for more yields of flowers and essential oil with horticultural improvement effects of pruning and amino acids may help gardeners to achieve more benefits. This study aimed to investigate the effects of pruning intensity (without pruning, 40,60 or $75 \mathrm{~cm}$ above ground level) and foliar application of amino acids (without amino acids, tryptophan or glycine) on jasmine shrubs for promoting growth and reproductive growth and the content of essential oil. The results showed that plants with light pruning $(75 \mathrm{~cm})$ and foliar application of amino acids especially glycine had the best growth and yield, which means that plants were affected by the interactions of pruning level and application of amino acids.
\end{abstract}

Keywords: arabian jasmine, essential oil, horticultural practice, reproductive growth, vegetative growth.

\section{Resumo}

Intensidade de brotação e aminoácidos triptofano e glicina no crescimento e floração de Jasminum sambac O Jasmim (Jasminum sambac L.) é um arbusto perene e muito perfumado, que tem grande importância na indústria da perfumaria e suas flores são utilizadas em diferentes cerimônias religiosas e cerimoniais. Formar os arbustos para obter mais safras de flores e óleo essencial com técnicas da horticultura de poda e aminoácidos pode ajudar os jardineiros a obter mais benefícios. Este estudo teve como objetivo investigar os efeitos da intensidade da poda (sem poda, 40, 60 ou $75 \mathrm{~cm}$ acima do solo) e da aplicação foliar de aminoácidos (sem aminoácidos, triptofano ou glicina) em arbustos de jasmim para promoção do crescimento e crescimento reprodutivo e teor de óleo essencial. Os resultados mostraram que as plantas com poda leve $(75 \mathrm{~cm})$ e aplicação foliar de aminoácidos principalmente glicina tiveram o melhor crescimento e rendimento, o que significa que as plantas foram afetadas pelas interações do nível de poda e aplicação de aminoácidos.

Palavras-chave: jasmim árabe, óleo essencial, prática hortícola, crescimento reprodutivo, crescimento vegetativo.

\section{Introduction}

Jasmine (Jasminum sambac L.) belongs to Oleaceae and is a subtropical or tropical plant. It is an evergreen shrub and very fragrant. Jasmine is very important in the perfume industry and its flowers are used in different religious and common ceremonies (Lokhande et al., 2015; Patil et al., 2018). There are more than 200 types of shrubs and climbers within the genus Jasminum. Its flowers are either white or yellow in colors. It is native to southwest Asia, but it spreads in the warm areas of South Asia, Pacific, Europe, and Africa (Bhattacharjee, 1980). J. sambac is one of three species of this genus that use in the perfume industry (Pawar et al., 2019). In 1753, Carl Linnaeus described it and named as Nyctanthes sambac, William Aiton reclassified it to the genus Jasminum and called it as Arabian jasmine (Watt, 1990). J. sambac is usually known as the "Tuscan Jasmine" or "Arabian Jasmine". In the perfume industry, the importance of jasmine is due to its essential oil compounds. Furthermore, its various parts, including stem, bark, leaf,

*Corresponding author: shafiee.masouleh@areeo.ac.ir, shafyii@gmail.com 
fruit, and seeds have medicinal properties. Essential oils are extensively applied in cosmetics, pharmaceuticals, perfumery, disinfectants, foods, and other products. The essential oils and extracts of numerous flowers like rose, jasmine, tuberose, etc. can be interested in high-grade perfumes and aroma therapy. The extraction of essential oils may be introduced as one of the main purposes of the cultivation of aromatic plants (Mahmood et al., 2017). The essential oil of J. sambac L. contains several compounds, including alkaloids, turbines, soaps, tannins, phenols, and volatile oils (Sabharwal et al., 2013).

The importance of pruning may be defined because of its roles to increase the growth and aesthetic value of plants. The time and intensity of the pruning affect the quality and quantity of flowers. There are important to provide nutrients for the flower bud initiation and benefit ventilation to minimize plant diseases (Pawar et al., 2019).

Plants may use amino acids as a source of nitrogen as well as inorganic nitrogen $\left(\mathrm{NH}_{4}^{+}\right.$and $\left.\mathrm{NO}_{3}^{-}\right)$. That said, plants may uptake amino acids as a whole molecule. These amino acids are in the soil and various factors affect the uptake of them, including their type and concentration (Geshnizjani and Khosh-Khui, 2016). Amino acids can improve plant growth by stimulating photosynthesis and act as part of enzymes (Amin et al., 2011). It acts in the formation of mRNA, sugars, proteins, and mineral groups through its association with the groups of carboxyl (-COO) and amine $\left(\mathrm{NH}_{2}\right)$, thus affect the biological composition of tryptophan that is formed in the phosphorylation cycle. Tryptophan plays a role in the formation of IAA and hence its important role is the accelerating of growth through the formation of plant tissues. It also plays a role in the decomposition of dead cells to proteins and thus stimulating plant growth, thus it has many effects on the growth and flowering of the plant (Khattab et al., 2016).

This research aimed to study the effects of pruning intensity and foliar application of amino acids for increasing flower yield and essential oil contents in $J$. sambac. The first is one of the important demands from gardeners who complain about the lack of flowers and a short period of flowering. And the second has importance for the perfume industry.

\section{Materials and methods}

The experiment was conducted in one of the home gardens in Al-Sharqat district, north of Salah Al-Din province ( $250 \mathrm{~km}$ north of Baghdad, Iraq), for nine month in 2019 on three-year Jasminum sambac shrubs with a height of $120 \mathrm{~cm}$ planted in the flower beds with 2 meters spaces between the shrubs. The experiment included two factors, the first factor was the pruning intensity in four levels (without pruning, $45,60,75 \mathrm{~cm}$ above ground level). The pruning treatment was carried out in mid-February 2019. And the second factor has three levels, including without addition, spraying with the amino acid tryptophan at a concentration of 1000 $\mathrm{mg} \mathrm{L}^{-1}$ and glycine at a concentration of $1000 \mathrm{mg} \mathrm{L}^{-1}$. The foliar application was carried out in mid-March 2019 and was repeated three times every 15 days. The experiment was carried out as a randomized complete block design (RCBD) with 4 replications and 2 shrubs (experimental units) per replication. The following characteristics were studied: plant height $(\mathrm{cm})$, stem diameter $(\mathrm{mm})$, number of branches (branch/ plant), number of leaves (leaf/ plant), time to flower bud emergence (days), time to flowering (days), number of flowers (flower/ plant), flower diameter $(\mathrm{mm})$, flowering duration (days), stalk length $(\mathrm{cm})$, number of flowering clusters on the plant (cluster plant ${ }^{-1}$ ). To assay the amount of essential oil in the flowers $(\mu \mathrm{g} / 100 \mathrm{~g})$, the organic solvent method was used (Pensuk et al., 2007). The results were statistically analyzed using the SAS statistical software (v.2003) and the means were compared according to Duncan's multiple range test at 5\% probability.

\section{Results and discussion}

In the investigation of vegetative growth of jasmine plants, the highest of plant height affected by the interaction of pruning intensity and foliar applications of amino acids was observed in the level of $75 \mathrm{~cm}$ and spraying with glycine, and the lowest was seen in plants without pruning and without spaying (Table 1). However, stem diameter showed an inverse trend compared to the plant height affected by interactions of pruning level and application of amino acids, and with more severe pruning the stem diameter was increased (Table 1). 
Table 1. The effect of pruning levels and amino acids on the vegetative and reproductive growth of Jasminum sambac.

\begin{tabular}{|c|c|c|c|c|c|c|c|c|}
\hline \multicolumn{2}{|c|}{ Treatments } & \multicolumn{4}{|c|}{ Vegetative growth } & \multicolumn{3}{|c|}{ Reproductive growth } \\
\hline PI & Am & $\mathbf{P H}$ & SD & NB & NL & $\mathbf{B E}$ & DF & NF \\
\hline \multirow{3}{*}{$\mathrm{C}$} & $\mathrm{C}$ & $82.17 \mathrm{~cd}$ & $6.65 c$ & $15.33 \mathrm{~d}$ & $164.33 f$ & $21.33 \mathrm{a}$ & $17.22 \mathrm{a}$ & $11.52 \mathrm{~g}$ \\
\hline & Try & $83.28 \mathrm{c}$ & $6.74 \mathrm{c}$ & $15.44 d$ & $172.66 \mathrm{e}$ & $18.44 b$ & $17.44 \mathrm{a}$ & $12.63 f$ \\
\hline & Gly & $85.92 b$ & $7.13 b$ & $17.33 b$ & $182.33 c$ & $17.33 c$ & $16.33 a$ & $14.25 \mathrm{e}$ \\
\hline \multirow{3}{*}{40} & $\mathrm{C}$ & $80.12 \mathrm{e}$ & $7.20 \mathrm{~b}$ & $16.33 \mathrm{c}$ & $152.12 \mathrm{~h}$ & $15.66 \mathrm{e}$ & $16.44 \mathrm{a}$ & $13.72 \mathrm{ef}$ \\
\hline & Try & $81.43 \mathrm{~d}$ & $7.37 b$ & $18.44 \mathrm{a}$ & $161.18 \mathrm{~g}$ & $15.44 \mathrm{e}$ & $15.66 b$ & $15.40 \mathrm{~d}$ \\
\hline & Gly & $83.17 \mathrm{c}$ & $8.19 \mathrm{a}$ & $18.33 \mathrm{a}$ & $173.55 \mathrm{e}$ & $17.55 \mathrm{c}$ & $14.44 \mathrm{c}$ & $17.20 \mathrm{c}$ \\
\hline \multirow{3}{*}{60} & $\mathrm{C}$ & $81.29 \mathrm{~d}$ & $7.23 b$ & $14.66 \mathrm{e}$ & $162.66 \mathrm{~g}$ & $18.33 b$ & $15.55 b$ & $12.31 \mathrm{f}$ \\
\hline & Try & $82.34 \mathrm{~cd}$ & $7.35 b$ & $15.66 \mathrm{~d}$ & $165.33 f$ & $17.11 \mathrm{c}$ & $15.44 b$ & $14.62 \mathrm{e}$ \\
\hline & Gly & $84.52 \mathrm{bc}$ & $7.31 \mathrm{~b}$ & $16.44 \mathrm{c}$ & $178.44 d$ & $17.33 \mathrm{c}$ & $15.33 b$ & $15.31 \mathrm{~d}$ \\
\hline \multirow{3}{*}{75} & $\mathrm{C}$ & $85.72 b$ & $8.16 a$ & $17.66 \mathrm{~b}$ & $190.33 b$ & $17.33 \mathrm{c}$ & $15.33 b$ & $17.80 \mathrm{c}$ \\
\hline & Try & $87.61 \mathrm{a}$ & $8.24 a$ & $18.44 \mathrm{a}$ & $195.44 \mathrm{a}$ & $16.44 d$ & $14.66 c$ & $18.60 \mathrm{~b}$ \\
\hline & Gly & $88.19 \mathrm{a}$ & $8.31 \mathrm{a}$ & $18.33 \mathrm{a}$ & $197.77 \mathrm{a}$ & $15.33 \mathrm{e}$ & $13.55 \mathrm{~d}$ & $19.33 \mathrm{a}$ \\
\hline
\end{tabular}

The means per column with similar letters are not significant at 5\% (Duncan's multiple range tests). Pl; Pruning levels (cm), Am; Amino acids, Control; C, Try; Tryptophan, Gly; glycine, PH; Plant height (cm), SD; Stem diameter (cm), NB; No. branches plant ${ }^{-1}$, NL; No. leave plant ${ }^{-1}$, BE; Bud emergence (days), DF; Days to flowering, NF No. flowers plant ${ }^{-1}$.

The branches/plant in plants without pruning and spaying was the highest and in severe pruning $(40 \mathrm{~cm})$ and foliar application with tryptophan or without spraying, and level of $75 \mathrm{~cm}$ (light pruning) and application of glycine was the lowest. Therefore, pruning may be important in making ventilation between branches in shrub regardless of the amino acid application (Table 1).

Plants with light pruning $(75 \mathrm{~cm})$ and foliar application of tryptophan and glycine could produce more leaves, and lack of pruning ore severe pruning caused lower leaf unfolding. That said, light pruning compensated a lack of amino acids compared to severe levels of pruning (Table 1).

In terms of reproductive growth (Table 1), the pruning regardless of its intensity $(75 \mathrm{~cm}$ or $40 \mathrm{~cm})$ and application of amino acids caused the latest bud emergence compared to without pruning and spraying. The most flower number was observed in light pruning $(75 \mathrm{~cm})$ with both amino acids and the least was observed with $40 \mathrm{~cm}$ and without spraying with amino acids. It seems that the foliar application of glycine could enhance flower numbers more in the level of pruning.

Based on Table 1, vegetative and reproductive growth was obtained with light or moderate pruning and the application of amino acids; this can be explained by making optimum conditions for photosynthesis through sufficient sunlight and supplying nitrogen, respectively. This explanation can be seen in others' research such as in J. auriculatum, Khanchana and Jawaharlal (2019) reported that pruning time and height affect growth and developmental factors, including plant height, canopy, and the number of shoots. They determined $30 \mathrm{~cm}$ from ground level for having the maximum number of shoots per plant in October compared to November. They determined this effect of optimum temperature and photoperiod in October. Moreover, they observed maximum flower by pruning in October and their reasons were due to more photosynthesis and more assimilation to produce flowers. Hasanuzzaman et al. (2018) observed that exogenous glutathione regulated proline, maintained tissue water status, and prevented chlorophyll degradation, and increased plant growth and biomass. du Toit et al. (2019) reported that moderate pruning ( $2 \mathrm{~m}$ above ground level compared to severe $(1 \mathrm{~m}$ above ground level) and light ( $3 \mathrm{~m}$ above ground level)) in Moringa oleifera Lam. increased earlier flowering, flower and fruit number, fresh and dry weights, leaf area index and stem diameter. Geshnizjani and Khosh-Khui (2016) in their reports quoted other's findings for application of amino acids in Iberis amara L. (foliar application of tryptophan), lemongrass and Datura (application of ornithine and phenylalanine), Pelargonium graveolens, Lupinus termis and Matricaria chamomilla (application of phenylalanine). They quoted that vegetative growth, fresh and dry weights increased under the effects of amino acids. Talaat et al. (2005) observed that the application of tryptophan in Catharanthus roseus L. increased chlorophylls and carotenoids. Rashad et al. (2002) showed that the application of amino acids in Capsicum annuum $\mathrm{L}$. increased photosynthetic pigments.

Amino acids play role in protective activities of plants, including cellular osmotic adjustment, detoxification of reactive oxygen species, maintain of membrane integrity, and stabilization of enzymes and proteins (Talukder et al., 2018). Talukder et al. (2018) reported the roles of amino acids hydroxyproline and glutamic acid on increasing 
growth and yield of strawberry, and more fruit number with glutamic acid compared to the control.

In gladiolus plant, the lowest concentration from any of the used amino acids (glycine at $75 \mathrm{mg}^{-1} \mathrm{~L}$ or methionine at $150 \mathrm{mg} \mathrm{L}^{-1}$ or tryptophan at $300 \mathrm{mg} \mathrm{L}^{-1}$ ) caused the best yield of vegetative, reproductive, and biochemical characteristics regardless of application method i.e. presoaking of corms or foliar application (Khattab et al., 2016). In Abelmoschus esculentus L., both soil and foliar application of L-tryptophan, which is auxin precursor, improved photosynthetic rate with increasing chlorophyll content and yield (Mustafa et al., 2016).

In the evaluation of the interaction of pruning intensity and foliar application of amino acids on flower characteristics, flower diameter was observed more with 75 $\mathrm{cm}$ (light level) and spraying with glycine and tryptophan, respectively, however, in severe pruning levels (40 and 60 $\mathrm{cm}$ ) glycine was more effective (Table 2).

Table 2. The effect of pruning levels and amino acids on flower development and essential oil content of Jasminum sambac.

\begin{tabular}{|c|c|c|c|c|c|c|}
\hline PI & Am & FD & FL & FSL & NFC & EO \\
\hline \multirow{3}{*}{$\mathrm{C}$} & $\mathrm{C}$ & $22.65 \mathrm{e}$ & $43.55 \mathrm{e}$ & $17.31 \mathrm{~b}$ & $1.55 \mathrm{~d}$ & $67.12 f$ \\
\hline & Try & $25.27 \mathrm{~d}$ & $48.44 d$ & $19.21 \mathrm{a}$ & $1.66 \mathrm{~d}$ & $71.23 \mathrm{c}$ \\
\hline & Gly & $29.55 c$ & $51.33 \mathrm{c}$ & $20.54 a$ & $2.44 \mathrm{c}$ & $72.02 \mathrm{c}$ \\
\hline \multirow{3}{*}{40} & $\mathrm{C}$ & $23.55 \mathrm{e}$ & $51.55 \mathrm{c}$ & $13.20 \mathrm{f}$ & $1.33 \mathrm{~d}$ & $70.19 \mathrm{e}$ \\
\hline & Try & $30.35 b$ & $53.66 \mathrm{~b}$ & $14.52 \mathrm{e}$ & $1.66 \mathrm{~d}$ & $72.17 \mathrm{c}$ \\
\hline & Gly & $28.21 \mathrm{c}$ & $55.22 \mathrm{a}$ & $16.07 \mathrm{c}$ & $2.22 \mathrm{c}$ & $74.34 b$ \\
\hline \multirow{3}{*}{60} & $\mathrm{C}$ & $28.45 c$ & $44.55 \mathrm{e}$ & $14.94 \mathrm{e}$ & $2.33 \mathrm{c}$ & $69.30 \mathrm{f}$ \\
\hline & Try & $31.65 b$ & $49.33 d$ & $16.21 \mathrm{c}$ & $3.55 b$ & $69.49 f$ \\
\hline & Gly & $33.05 \mathrm{a}$ & $54.33 \mathrm{a}$ & $17.02 \mathrm{~b}$ & $4.22 \mathrm{a}$ & $70.13 \mathrm{e}$ \\
\hline \multirow{3}{*}{75} & $\mathrm{C}$ & $26.55 \mathrm{~d}$ & $49.66 \mathrm{~d}$ & $15.25 \mathrm{~d}$ & $2.33 \mathrm{c}$ & $74.31 \mathrm{~b}$ \\
\hline & Try & $33.07 \mathrm{a}$ & $54.44 \mathrm{a}$ & $16.35 \mathrm{c}$ & $2.55 \mathrm{c}$ & $75.43 a$ \\
\hline & Gly & $34.14 \mathrm{a}$ & $53.33 b$ & $19.70 \mathrm{a}$ & $3.44 \mathrm{~b}$ & $76.73 a$ \\
\hline
\end{tabular}

The means per column with similar letters are not significant at 5\% (Duncan's multiple range tests). Pl; Pruning levels (cm), Am; Amino acids, Control; C, Try; Tryptophan, Gly; glycine, FD; Flower diameter (mm), FL; Flower longevity (days), FSL; Flower stalk length (cm), NFC; No. flower clusters/ plant, EO; Essential oil content (EO)

Abd-Elkader et al. (2020) reported that the mixed foliar application $\left(100 \mathrm{mg} \mathrm{L}^{-1}\right)$ of amino acids glycine, arginine, asparagine, alanine, and tryptophan in one-month-old gerbera plants caused the highest values of fresh and dry weights, flower diameter and photosynthetic pigments compared to a single application of amino acids and the control.

Flower longevity (the duration that plants were in flowering) with the level of $60 \mathrm{~cm}$ and glycine was the longest, and the lightest level of pruning $(75 \mathrm{~cm})$ especially with glycine was in the second rank to have the longest flowering. Therefore, pruning in the lightest levels are better compared to severe or without pruning (Table 2). Abdossi and Danaee (2019) observed more longevity of flowers in Dianthus caryophyllus L. affected by $100 \mathrm{mg} \mathrm{L}^{-1}$ glutamine and more activities of catalase, superoxide dismutase, peroxidase, and phenylalanine ammonialyase enzymes affected by phenylalanine at $100 \mathrm{mg} \mathrm{L}^{-1}$. Therefore, it may be explained that the suitable level of pruning and better photosynthesis performance and supply of precursors of proteins (amino acids) even through artificial supplying may affect the longest flowering in plants.
Glycine in all levels of pruning caused more flower stalk length, and plants without pruning had longer flower stalk, which seems not to be suitable in terms of ornamental value. Numbers of flower clusters/ plant were the most in all of the pruning levels with glycine, however, in $75 \mathrm{~cm}$ was the most with tryptophan (Table 2). Pruning is an important horticultural practice to ease flower harvesting, suitable light distribution in plant canopies, production of high-quality flowers, and removing diseases. Pawar et al. (2019) and Kumaresan et al. (2017) reported that the pruning level in $J$. sambac causes more growth of plant and more buds per plant. They explained this due to the production and accumulation of more assimilates. Moreover, they reported that the interaction of pruning time and intensity was effective. Pawar et al. (2019) determined the maximum flower yield obtained through $50 \mathrm{~cm}$ pruning from the ground level compared to from $25 \mathrm{~cm}$ ground level. Lokhande et al. (2015) did not find any significant interaction between pruning time and level but observed significant main effects of timing and intensity. They reported the level of $30 \mathrm{~cm}$ from ground level as the best pruning level to produce more flowers in $J$. 
sambac. In Jasmine, flower production can be enhanced by horticultural practice such as pruning.

Pruning causes the growth of new healthy shoots with more flowers on old stems. It makes for plants a benefit canopy. Therefore, pruning is horticultural management as well as nutrient management and plant density (Lokhande et al., 2015). Akhtar et al. (2016) explained that moderate pruning in both species of Rosa centifolia and $R$. damascena increased flowering and this can be helpful for essential oil yield. Singh and Kaur (2019) stated that pruning in guava cv. L-49 as severe (30 $\mathrm{cm}$ of apical shoots compared to 10 and $20 \mathrm{~cm}$ ) on $15^{\text {th }}$ May compared to latest dates improved yield and fruit quality such as TSS, sugars, ascorbic acids and pectin content of fruits.

The content of essential oil with all level of pruning except $40 \mathrm{~cm}$ was the highest with glycine, and in the level of $75 \mathrm{~cm}$ there is no significant difference between two amino acids (Table 2). Aghaei et al. (2019) indicated that spraying of 1-phenylalanine on hyssop increased growth and growth characteristics and essential oil of aerial parts of plants. They explained that the supplying of nitrogen through amino acids caused the increased activities of photosynthesis pigments and secondary metabolites such as essential oil. It may be said, spraying of amino acids can solve the request of plants for nitrogen to synthesize the secondary metabolite such as essential oil.

\section{Conclusions}

In conclusion, it can be recommended the light $(75$ $\mathrm{cm})$ or moderate $(60 \mathrm{~cm})$ pruning with foliar application of glycine for achieving the highest yield of jasmine plants. Based on the results and literature it may be explained even light pruning $(75 \mathrm{~cm})$ can compensate the lake of applications of amino acids to have more yield of flowers and essential oil and longest flowering.

\section{Author Contribution}

ZKS: arranged the research and the results. SSSM: wrote the paper and edited it and its integrity. MAA and MAS: performed the experimental sections and analyzed the data.

\section{Acknowledgments}

The authors would like to acknowledge Tikrit University, Iraq and the Deputy of Research and Technology in Horticultural Sciences Research Institute (HSRI), Iran to perform and report the research.

\section{References}

ABD-ELKADER, H.H.; MASSOUD, H.Y.; EL-BAZ, T.T.; EL-ERIAN, M.A. Effect of amino acids spray on growth, flowering and keeping quality of Gerbera jamesonii L. as a pot plant. Journal of Plant Production, v.11, n.2, p.201-6, 2020. DOI: https://doi.org/10.21608/jpp.2020.79110
ABDOSSI, V.; DANAEE, E. Effects of some amino acids and organic acids on enzymatic activity and longevity of Dianthus caryophyllus cv. Tessino at pre-harvest stage. Journal of Ornamental Plants, v.9, n.2, p.93-104, 2019.

AGHAEI, K.; PIRBALOUTI, A.G.; MOUSAVI, A.; BADI, H.N.; MEHNATKESH, A. Effects of foliar spraying of 1-phenylalanine and application of bio-fertilizers on growth, yield, and essential oil of hyssop [Hyssopus officinalis 1. subsp. Angustifolius (Bieb.)]. Biocatalysis and Agricultural Biotechnology, v.21, p.101318, 2019. DOI: https://doi.org/10.1016/j.bcab.2019.101318

AKHTAR, G.; AKRAM, A.; SAJJAD, Y.; FAROOQ, A.; BALAL, R.M.; YOUNIS, A.; LIM, K.B. Improving flower yield of two essential oil bearing rosa species through pruning severity. Pakistan Journal of Nutrition, v.15, n.4, p.328, 2016. DOI: https://doi.org/10.3923/ pjn.2016.328.332

AMIN, A.A.; GHARIB, F.A.; EL-AWADI, M.; RASHAD, E.S. Physiological response of onion plants to foliar application of putrescine and glutamine. Scientia horticulturae, v.129, n.3, p.353-60, 2011. DOI: https://doi. org/10.1016/j.scienta.2011.03.052

BHATTACHARJEE, S.K. Native Jasmine of India. Indian Perfumer, v.24, n.3, p.126-133, 1980.

DU TOIT, E.S.; SITHOLE, J.; VORSTER, J. Pruning intensity influences growth, flower and fruit development of Moringa oleifera Lam. under sub-optimal growing conditions in Gauteng, South Africa. South African Journal of Botany, 2019. DOI: https://doi.org/10.1016/j. sajb.2019.11.033

GESHNIZJANI, N.; KHOSH-KHUI, M. Promoted growth and improved quality of Gerbera jamesonni L. flowers using exogenous application of amino acids. International Journal of Horticultural Science and Technology, v.3, n.2, p.155-66, 2016. DOI: https://doi.org/10.22059/ ijhst.2016.62915

HASANUZZAMAN, M.; NAHAR, K.; RAHMAN, A.; MAHMUD, J.A.; ALHARBY, H.F.; FUJITA, M. Exogenous glutathione attenuates lead-induced oxidative stress in wheat by improving antioxidant defense and physiological mechanisms. Journal of Plant Interactions, v.13, n.1, p.203-12, 2018. DOI: https://doi.org/10.1080/17 429145.2018.1458913

KHANCHANA, K.; JAWAHARLAL, M. Influence of different pruning months on growth and flowering of Jasminum auriculatum. Journal of Pharmacognosy and Phytochemistry, v.8, n.3, p.3654-6, 2019. 
KHATTAB, M.; SHEHATA, A.; ABOU EL-SAADATE, E.; AL-HASNI, K. Effect of Glycine, Methionine and Tryptophan on the vegetative growth, flowering and corms production of Gladiolus plant. Alexandria Science Exchange Journal, v.4, n.37, p.647-59, 2016. DOI: https:// doi.org/10.21608/asejaiqjsae.2016.2543

KUMARESAN, M.; RAJADURAI K.R.; GANGA, M.; SIVAKUMAR, R. Effect of pruning and paclobutrazol application on physiological and flowering characters of jasmine (Jasminum sambac L.) during off Season. IJCS, v.5, n.5, p.2374-8, 2017.

LOKHANDE, S.; CHOPDE, N.; WASNIK, P.; NEHARE, N. Response of Jasminum sambac (L.) to time and severity of pruning. Plant Archives, v.15, n.2, p.759-62, 2015.

MAHMOOD, M.A.; MUHAMMAD S.; NAVEED A. Quantitative and qualitative analysis of essential oil of arabian jasmine (Jasminum sambac) flowers harvested from Pothohar Region of Pakistan. Journal of Ornamental Plants, v.7, n.1, p.17-24, 2017.

MUSTAFA, A.; HUSSAIN, A.; NAVEED, M.; DITTA, A.; NAZLI, Z.E.; SATTAR, A. Response of okra (Abelmoschus esculentus L.) to soil and foliar applied L-tryptophan. Soil \& Environment, v.35, n.1, 2016.

PATIL, S.; CHOPDE, N.; PATOKAR, M.J. Integrated nutrient management studies in Jasminum sambac L. Journal of Pharmacognosy and Phytochemistry, v.7, n.2, p.3778-80, 2018.

PAWAR, R.; BHATT, S.T.; BHATT, D. Influence of time and level of pruning on flowering yield in Jasminum sambac var. Baramasi under South Gujarat condition. Journal of Pharmacognosy and Phytochemistry, v.8, n.2, p.1975-7, 2019.
PENSUK, W., PADUMANONDA, T., PICHAENSOONTHON, C. Comparison of the chemical constituents in Michelia alba flower oil extracted by steam distillation, hexane extraction and effleurages method. Journal of Thai Traditional \& Alternative Medicine, v.5, n.1, p.30-9, 2007.

RASHAD, E.S.; HABBA, E.E.; FARAHAT, M.M. Growth, fruiting and active ingredient hot pepper plants as affected by phenylalanine, cinamic acid and coumaric acid. Egyptian Journal of Applied Sciences, v.17, n.12, p.698715, 2002. DOI: https://doi.org/10.1079/IVP2005708

SABHARWAL, S.; SUDAN, S.; RANJAN, V. Jasminum sambac linn (motia): a review. International Journal of Pharmaceutical research and bio-science, v.2, n.5, p.108-30, 2013.

SINGH, H.R.; KAUR, A. Effect of pruning intensity and time on yield and quality of guava cv. L-49. Research on Crops, v.20, n.3, p.525-30, 2019. DOI: https://doi. org/10.31830/2348-7542.2019.075

TALAAT, I.M.; BEKHETA, M.A.; MAHGOUB, M.H. Physiological response of periwinkle plants (Catharanthus roseus L.) to tryptophan and putrescine. International Journal of Agriculture and Biology, v.7, n.2, p.210-3, 2005.

TALUKDER, M.R.; ASADUZZAMAN, M.; TANAKA, H.; ASAO, T. Light-emitting diodes and exogenous amino acids application improve growth and yield of strawberry plants cultivated in recycled hydroponics. Scientia Horticulturae, v.239, p.93-103, 2018. DOI: https://doi. org/10.1016/j.scienta.2018.05.033

WATT, G. A dictionary of the economic products of India. London: WH Allen; Calcutta: Superintendent of Government Printing, 1893. 1189p. 